\title{
乳幼児水頭症のシャント術後の脳室の形態と知能予後との関係
}

\author{
加藤 誠
}

\section{Relationship between Ventricular Configuration and Intelligence after Surgery in Infantile Hydrocephalus}

\author{
Makoto KATO \\ Department of Neurological Surgery, Chiba University, Chiba
}

\begin{abstract}
The author studied the ventricular configurations after shunt operation on 60 cases of infantile hydrocephalus followed for more than two years using computed tomography (CT). Follow-up periods ranged from two years to 14 years and six months. The cases consisted of 24 cases of congenital hydrocephalus ( 19 of which were followed up for more than five years), 10 cases associated with meningocele ( 7 cases followed more than five years), 4 with malformation ( 3 cases), 9 cases after bleeding ( 3 cases), and 13 cases after meningitis $(7$ cases). Excluding those cases accompanying apparent encephalodysplasia, 39 cases were followed for more than 5 years and the relationship between their intelligence and ventricular configuration on $\mathrm{CT}$ was investigated. They were classified into four categories of intelligence based on school performance and conditions of daily life, and into six types of ventricular configulations on CT: I) slit like ventricle; II) normal; III) slightly dilated; IV) extremely dilated; V) irregular shape; and VI) accompanying cerebral atrophy. The ventricular configulation after operation correlated with the intelligence. Cases with excellent or good intelligence were found in CT Types I, II, and III. Cases of congenital hydrocephalus operated in infancy often showed slit-like ventricle and excellent or good intelligence. There was no discrepancy between verbal IQ and performance IQ of WISC in the excellent intelligence group. Ventricular configurations became stable almost within one year after operation.
\end{abstract}

Key words: hydrocephalus, computed tomography, intelligence

\section{I はじめに}

主として，乳児期に治療の行われる水頭症患児の知能予 後を左右する因子については，従来より水頭症の程 度 ${ }^{5,9}$ ${ }^{30)}$, 手術時期 ${ }^{5,9,14,28,303}$, 基礎疾患 ${ }^{14,24,30)}$, 両視の知能 程 度20,27) などが举げられている。しかし，術後の computed tomography(以下CT と略す) と知能予後との関係を述べた 報告は多くはない2,13)。

今回，水頭症患児の知能予後について，(1)術後のCT所 見と知能予後とが一致するか，(2)もし一致するなら，術後 のCT芹見よりいつ知能予後を推定しらるかについて検討 したので報告する。

\section{II 対象および方法}

\section{1. 症例}

対象は, 脑盾瘍に起因するもの抒よび明らかな脳形成不 全を伴亏症例を除いた乳幼児水頭症の5ち, 術後 2 年以上 追跡し，CT にてその脳室の形態を調べることのできた 60 例である(追跡期間は 2 年以上，最長 14 年 6 力月，平均 6 年 5 力月). 5 年以上の追跡例については CT による脳室 の形態と知能予後に関し， 2 年以上 5 年未満例では CTK よる術後の媨室の形状の変化について検討した，症例の内 訳法, 先天性単純水頭症24例 ( 5 年以上追跡例19例), 䯣膜 瘤江伴亏水頭症 10 例 ( 7 例), 他の奇形・先天性異常を伴 5 水頭症 4 例 ( 3 例), 後頭蓋窩 arachnoid cyst を伴 $う$ も 3 


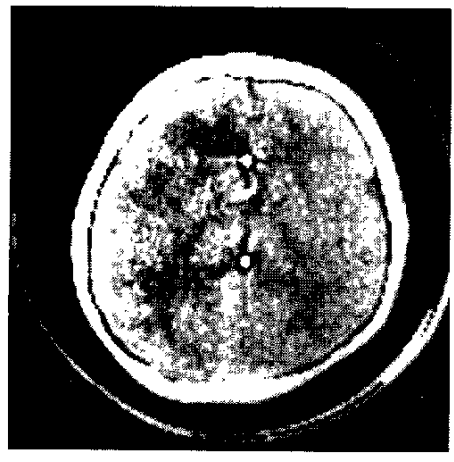

I

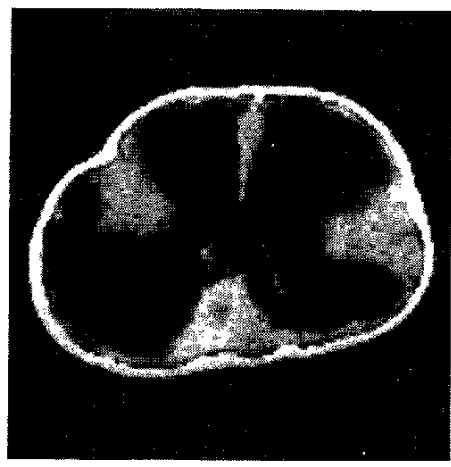

IV

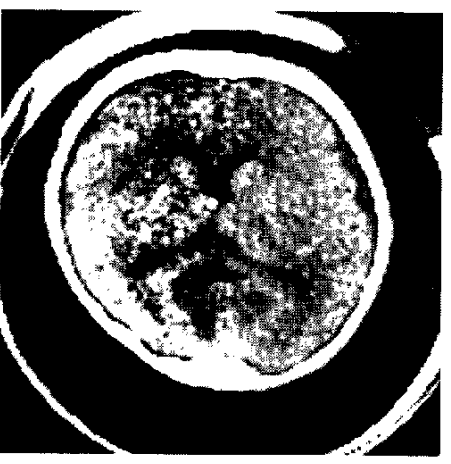

II

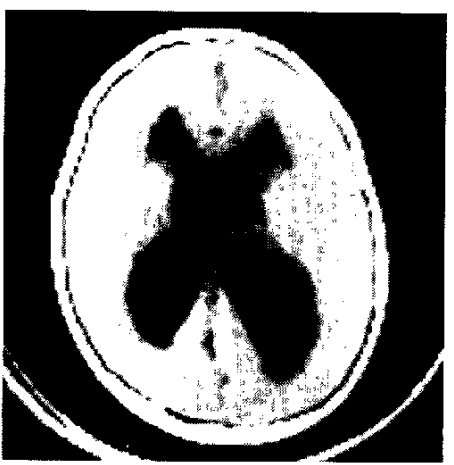

V

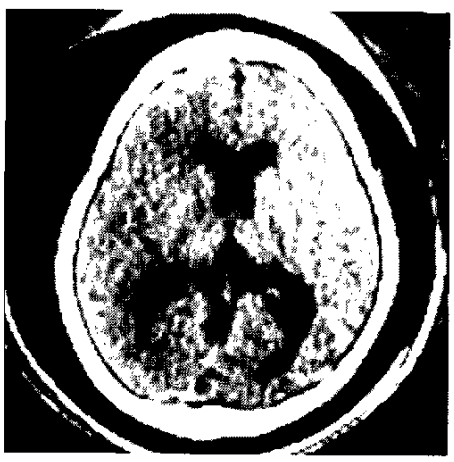

III

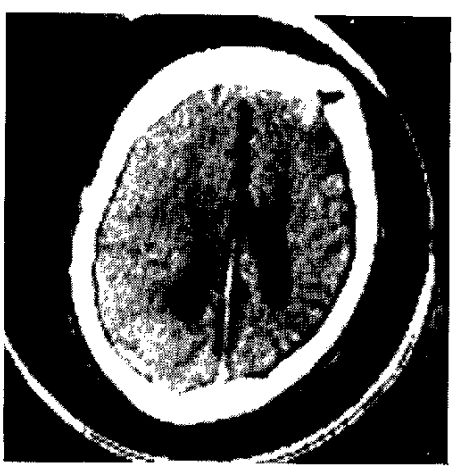

VI

Fig. 1 Typc I: slit-like ventricle, II: normal, III: slightly dilated, IV: extremely dilated, V: irregular shape, VI: accompanying cerebral atrophy.

Table 1 Followed-up cases of infantile hydrocephalus

\begin{tabular}{|c|c|c|c|c|}
\hline \multicolumn{5}{|l|}{ Cases } \\
\hline $\begin{array}{l}\text { congenital simple hydro- } \\
\text { cephalus }\end{array}$ & : & 24 cases & (19 cases & \\
\hline associated with meningocele & : & 10 & $(7$ & ) \\
\hline accompanying malformation & : & 4 & $(3$ & ) \\
\hline $\begin{array}{l}\text { after intraventricular } \\
\text { hemorrhage }\end{array}$ & : & 9 & $(3$ & ) \\
\hline \multirow[t]{2}{*}{ after meningitis } & $:$ & 13 & $(7$ & ) \\
\hline & : & 60 & $(39$ & ) \\
\hline
\end{tabular}

( ): followed up over 5 ycars

例, primary progressive muscle dystrophia に伴うむの 1 例 頭蓋内出血後水頭症 9 例 ( 3 例), 儎膜炎後水頭症 13 例 ( 7 例)である(Table 1).

\section{2. 手術方法および手術時期}

手術は原則として檤室一腹腔短絡術を右側脑室前角に行 い，再手術などではときに左前角，後角に(延総数128例)， または腷室一心房短絡術 (延総数 8 例)を施行した。用いた valve, tube は Pudenz 式であり，腹腔内压注 $50 \mathrm{mmH}_{2} \mathrm{O}$ 前 後とし, antisiphonは用いず，腹腔内の tube の長さは 20 $\sim 30 \mathrm{~cm}$ とした.

初回手術年龄は生後 1 力月未満15例, $1 \sim 6$ 力月 21 例,
Table 2 Surgical methods and timing

\begin{tabular}{|c|c|c|c|}
\hline \multirow{2}{*}{\multicolumn{2}{|c|}{$\begin{array}{l}\text { ventriculo-peritoneal shunt } \\
\text { ventriculo-atrial shunt }\end{array}$}} & \multicolumn{2}{|l|}{ total 128} \\
\hline & & total & \\
\hline \multicolumn{4}{|c|}{ age of first operation } \\
\hline under 1 month & $: \quad 15$ cases & $1-6$ months & $: 21$ \\
\hline $6-12$ months & $: \quad 12$ & 1-2 years & \\
\hline after 2 years & $: 8$ & & \\
\hline
\end{tabular}

6 力月 1才 12 例, 1 才 2 才 4 例， 2 才以上 8 例であっ た (Table 2).

\section{3. 知能予後の評価}

知能予後は，普通学級学業成績の中加ら上を cxcellent, 普通学級学業の成績下を good，特殊学級を fair，重症心身 障害者施設あるいは家庭看護を要するものを poor とし，4 段階に分類した。

\section{4. 術後の脳室の形態の分類}

術後の媨室の形態は，I 型：slit like ventricle(以下 SLV と略す)老呈するもの，II型：ほぼ正常なるの，III 型：軽 度から中等度㹡大を呈与るもの，IV型：高度に拡大したむ $の, \mathrm{~V}$ 型: 脳室の形態, 辺縁の不整なもの, VI型：明瞭な

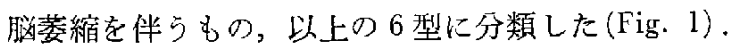


Table 3 Ventricular configuration and aetiology

\begin{tabular}{lcccccr}
\hline Type & $\begin{array}{l}\text { Con- } \\
\text { genital }\end{array}$ & $\begin{array}{l}\text { Menin- } \\
\text { goccle }\end{array}$ & $\begin{array}{l}\text { Malfor- } \\
\text { mation }\end{array}$ & $\begin{array}{l}\text { Bleed- Menin- } \\
\text { ing }\end{array}$ & \begin{tabular}{l} 
gitis \\
\cline { 5 - 6 } Total
\end{tabular} \\
\hline I & $15(10)$ & $5(3)$ & & $3(2)$ & $3(2)$ & $26(17)$ \\
II & $1(1)$ & & & $1(0)$ & $1(1)$ & $3(2)$ \\
III & $6(6)$ & $1(1)$ & $2(2)$ & & $1(0)$ & $10(9)$ \\
IV & & & & $1(0)$ & $2(1)$ & $3(1)$ \\
V & $2(2)$ & $4(3)$ & $2(1)$ & $1(1)$ & $1(1)$ & $10(8)$ \\
VI & & & & $3(0)$ & $5(2)$ & $8(2)$ \\
\hline Total & $24(19)$ & $10(7)$ & $4(3)$ & $9(3)$ & $13(7)$ & $60(39)$ \\
\hline
\end{tabular}

( ): followed up over 5 years

Table 4 Ventricular configuration and intelligence (followed up over 5 years)

\begin{tabular}{lcc|ccc}
\hline Type & Exccllent & Good & Fair & Poor & Total \\
\hline I & 13 & 1 & 3 & & 17 \\
II & 2 & & & & 2 \\
III & 5 & 2 & 2 & & 9 \\
\hline IV & & & 1 & & 1 \\
V & & & 5 & 3 & 8 \\
VI & & & 1 & 1 & 2 \\
\hline Total & 20 & 3 & 12 & 4 & 39 \\
\hline
\end{tabular}

\section{III 結 果}

\section{1. 術後の腷室の形態と基礎疾患との関係 (Table 3)}

総数60例のらち, 術後脳室がSLVになった群, すなるち I 型26例中先天性単純水頭症15例，髄膜瘤に伴 5水頭症 5 例, 出血後拉よび髄膜次後水頭症各 3 例であり， II型注先 天性单純水頭症, 出血後 - 骾膜炎後水頭症各 1 例, III型で

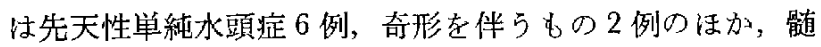
膜瘤を伴 5 もの・髄膜炎後水頭症各 1 例，IV型では出血後 1 例, 咀膜炎後 2 例, V型では先天性単純水頭症 2 例, 㵦 膜瘤に伴 5 も04 例, 奇形圭伴 5802 例, 出血後・髄膜 炎後各 1 例, VI型は出血後, 䯣膜炎後水頭症のみであり, おのおの3例および 5 例であった。

\section{2. 術後の畄室の形態亡知能予後との関係 (Table 4)}

術後 5 年以上追跡した39例について検討した。I 型では excellent 13例, good 1 例, fair 3 例であり poor はなかっ た、】型では excellent のみ(2例)，而型では excellent 5 例, good 2 例, fair 2 例であり, IV型では fair 1 例のみ, V 型では fair 5 例, poor 3 例, VI型では fair, poor 各 1 例で あった。以上のごとく I， I， III型では excellent, goodが 多く, 逆に脳室の高度な扡大, 脳室の形状不整, 脳琶縮孛 伴ら型，才なおちIV，V，VI型では excellent, good例はな く全例予後不良であった。生た I，III型の fair 5 例中 3 例
Table 5 Ventricular configuration, aetiology and intelligence (followed up over 5 years)

\begin{tabular}{|c|c|c|c|c|c|}
\hline Type & Excellent & Good & Fair & Poor & Total \\
\hline I & $\begin{array}{l}000000 \\
\square \square \square \\
* *\end{array}$ & 0 & 000 & & 17 \\
\hline II & $\stackrel{\bigcirc}{\%}$ & & & & 2 \\
\hline III & $\begin{array}{l}00 \\
{ }^{\star}\end{array}$ & 00 & 00 & & 9 \\
\hline IV & & & $※$ & & 1 \\
\hline V & & & $\begin{array}{l}\mathrm{O} \\
\square\end{array}$ & 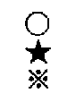 & 8 \\
\hline VI & & & 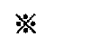 & $※$ & 2 \\
\hline Total & 20 & 3 & 12 & 4 & 39 \\
\hline
\end{tabular}

$\bigcirc$ : congenital, $\square$ : meningocele, $\star$ : malformation, : bleeding, $※$ : meningitis

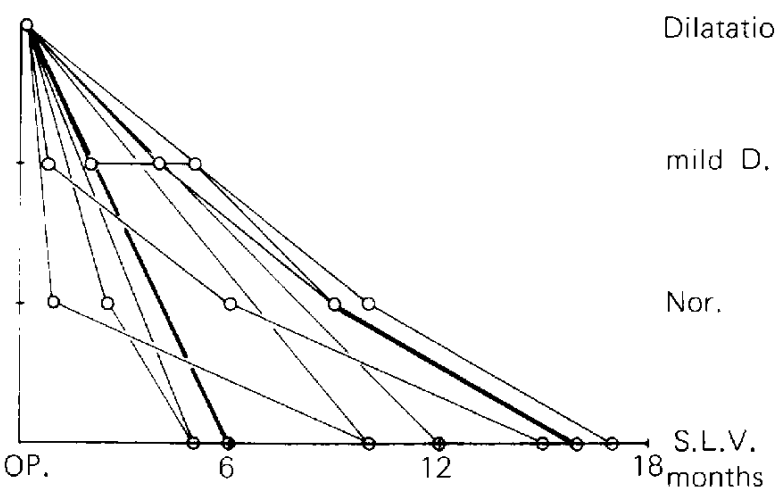

Fig. 2 Interval for the ventricle to become slit-like after the first operation. All cases showed slit-like ventricle within 17 months. OP: operation; D: dilatation; Nor.: normal; S.L.V.: slit-like ventricle

は初回手術時期が 2 才以後であり，1 例は再建術の時期が 遅かったものである。

\section{3. 基礎疾患亡術後の脳室の形態および知能予後しの関係} (Table 5)

先天性単純水頭症 $の 大$ 部分 (19例中17例) は，I，II，III 型となり予後良好であり，また髄膜瘤を伴った症例では， SLVおよび媨室应大の減少した群, 寸なわち I， III 型( 7 例中 4 例)では予後良好であるがV型では不良であった。 出血後・䯣膜炎後水頭症でも I, II型は予後良好であった が， IV，V，V型では不良であった，すなわち基礎疾患の いかんにかかわらす，I，I，而型を呈するものに予後良 
Table 6 Ventricular configuration and WISC

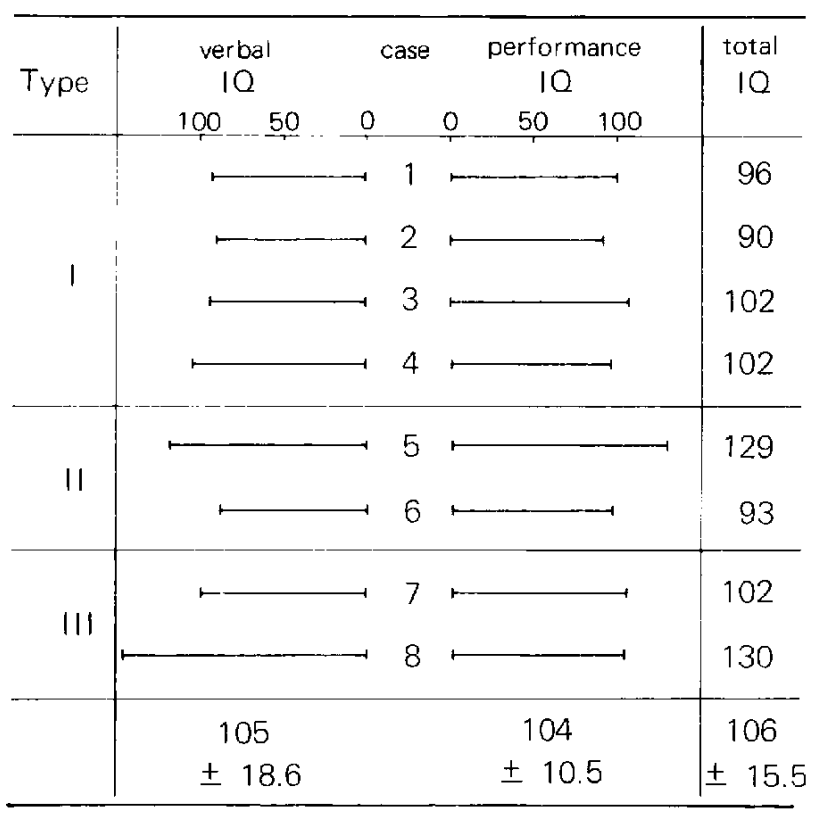

Table 7 Interval for the configuration of ventricle to become fixed after the first operation

Type II :
III : 12 months
IV : $\quad 2$ and 8 months
V : 4 and 10 months
VI : $\quad 6$ to 8 months

好例が多く，逆にIV，V，VI型では予後不良であった，

4. WISC (Table 6)

Excellent 群 8 例に WISC (Wechsler intelligence scale for children)を施行した．I型 4 例，II型・III型各 2 例（基礎 疾患は先天性単純水頭症 6 例, 髄膜炎後水頭症・他の奇形 を伴 5もの各 1 例)．各群の間に特飞差はなく，また言語 性 IQ と動作性 IQ との閐にも有意の差活認められなかっ た.

5. 術後脳室の形態が一定化するまでの期間 (Table 7,8)

知能予後を予測するに，術後どのくらいの期間を要する か，寸なわ術後脳室の形態が一定になるすでにどれくら いの期間を要するか子， 2 年以上 5 年末満の追跡例につい て検討した。初回手術後脳室が SLV になるまでは早くて 5 力月, 遅くとも17 月㐫り, 平均10.7力月であった。 12 力以上要した例は 4 例あったが，拉の括の 6 力月， 9 カ月，10力月に施行した亦上は行って招らず，頻繁に检查 を施行しておればょり早期に発見できたものと思われる。
また全例 5 力月以内に縮小傾向を示し，10力月以内に活 ぼ正常の大きさを示していた，基碟疾患别で法先天性単純 水頭症がやや遅い傾向を示した。他の群に関しては林型流 4 力月, III型は 12 力月 (各 1 例)，IV型は 2 力月栝よび 8 力 月( 2 例)，V型は 4 力月扰上び10力月 ( 2 例), V(型は, 6 力月加ら 8 力月後 (6 例) 飞は脳室の形態は固定化した。 すなわち知能予後と関連すると思われる脳室の形態は，ほ ほ 1 年にて判定できると思われる。またその縮小傾问より 判断すれば，術後ほぼ半年くらいで予後を予測できるもの と思われる。

\section{$\mathrm{N}$ 考察}

従来，水顽症の状態を把握するために臨床症状，放射線 学的, 核医学的に検查してきたが， CT の普及に上り脳室 の形態を調べることがより容易となり，術前術後の脑室の 形態の変化を，患児に侵襲を与えることなく検索すること が可能であり，また明らかな脑形成不全の発見も容易とな った

さて，知能予後を左右寸る因子として手術時期，脑実質 幅, 基䃈疾患などが挙げられているが, 手術時期については 多くの人の指摘寸るところであり $50,2,14,28,30)$, 早期化手術 を施行寸ることが，上衣組織下の白質の荒廃索防ぎ，再構築 をらながし，良い知能予後が得られると言われている21,22, ${ }^{28)}$. 脳室の形態上知能予後については, 以前洨気脳写に上 る検菜が主であったため主に脳実質幅との関倸が論じられ

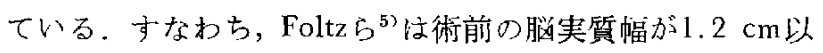
下, 伊東ら ${ }^{93}$ は $1.4 \mathrm{~cm}$ 以下では予後不良とし, またYoung $ら^{300}$ 活，予後良好上なるために注術後 $2.8 \mathrm{~cm}$ 以上要する と述べている.しかし, 脳実質幅の小さい例でも予後良好 となることは臨床的に経験するところであり，脳実質幅と 知能予後とはあまり関倸がないという意見もある亦る211,13,20, ${ }^{28,29)}$. Rubin $5^{22)}$ 江知能は夾白質の問題であり，水頭症は 白質の荒廃が主であるためこのよらな差が生じるのである らと推察している。一般には，上衣下組織の再構築の良い 症例恬ど知能予後注良好となると照われる。すなわち，脳 室の形態では縮小の認められる本シリーズ I， II， II 型が これに相当し，予後良好の結果々なったと思われる。一 方, CT では気脳写に比し脳室の拡大以外に腷実質の局所 的変化や脳表の変化の把握が容易であり, Lonton ${ }^{13)}$ 扣よび Bøttcher $ら^{2)}$ は, CT 所見と知能予後化関し, 前者注脑室 桩大に左右差のあるむの㧍よび孔㨫症のあるものに，また 後者は脑溝の広いもの注ど知能が低いと述べておる，本シ リーズのV型，VI型に相当するものと思われる. 以上のご とく、私の CTの分類は, 脳室の大きさのみならず脳実質 の変化庄く捉えて行われたものであり，知能予後を判定 
するら充では相関性の高いものと言えるであろう。しかし ながら，I型扔よび而型中にわずかでは亦るが予後の fair なものが含束机ている。これら活 2 才以上の初回手術例 と，シャント機能不全長期放坥例であった。シャント再建 の回数と予後上は関係ないと言われているが20,26)，シャン 卜機能不全に陷った際洨速や汃汇再建術在行万必要がある ことは言らまでもない，

ところだ，基礎疾忠と知能予後との相関性江本シリーズ では認められなかったが，従来の報告の中でも同様に関倸

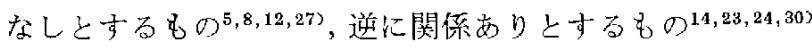
に分かれるが，乙れも基礎疾患そのものよりも，(1)その疾 患によって生じた腷の荒廃度の差, (2)悩そのものの奇形に 上るものであるうと思われる。すなわち，前者について は，髄膜炎後や出血後に脳空壁の不整，皮質の蒌縮をきた

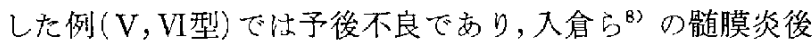
脳室内隔壁形成例は予後不良といら報告と一致する，(2) 亿 関しては, 髄膜瘤を伴う水顽症ではことに春椎破裂例に脳 の奇形が伴うことが言われて扔り $1,6,17,31)$ ，Gooding ら $5^{67}$ 仙 脳室撮影所見より，第三脳室前方の奇形，視床閒橋の扰大 および側脑室前角の下方の鋭角を指摘し，CT 所見でも視 床間橋の拡大，尾状核頭の突出17,31)，いわ活る“vampire bat”状の侧脳室 ${ }^{311}$ などが指摘され，これらは脳の奇形によ る二次的なものであるうと言われており，脳そのものの奇 形の存在が示唆されている。本シリーズに打けるI型にな るもの(予後良好)とV型のまま(予後不良)の差は，譄乞の むのの奇形の大小の差によるものかもしれない。

IQ 汇関しては, 髄膜瘤に伴う水頭症では一般に言語性 IQ に比し動作性 IQ が低いと言われているが ${ }^{1.7,26)}$,

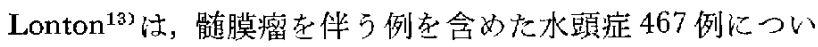
て検討しているが，や法り動作性 IQ が低いとして招り， また脑室の搪大度と言語性 IQ とは相関しないが，動作性 IQは脳室の掂大により差があること索指摘している，本 シリーズでは言語性 IQ と動作性 IQ との間に有意の差は 認められなかったが，対象を excellent 群に限定したため かもしれない。

最後に，脳室が術後一定化するまではほぼ１年を要する が，従来の報告 ${ }^{19,25)}$ でも術後 1 年以内に SLV となってお り，さらに頻繁に検索することによりまた脳室の縮小傾向 を把握することにより，よりいっそう早期に予後を判定し 万る可能性がある，また，一度 SLV になった症例がシャ ント機能不全を生じても，急激な腷室应大をきたさず，わ ずかな脳室の形態の差と臨床症状の変化のみを呈する場合

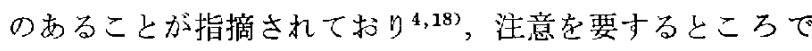
亦る。

\section{$\mathrm{V}$ ま $め$}

脑腫瘍に起因寸るもの，扝よび明らかな㨫形成不全を伴 った例老除いた乳幼児水頭症60例の術後のCT所見と予後 との関倸を検討した。

1. 術後の脳室の形態と知能予後とは, ある程度相関す る。(1)予後良好例注，脳室形態 I， II， III型记含孚れ，不 良例はIV，V，VI型に多い，(2)乳児期に手術した先天性単 純水頭症は，術後船室はSLV になることが多くかつ予後 良好である。

2. 予後良好例に施行したWISC では，言語性 IQと動 作性 IQとの間传差隹認められなかった。

3. 脳室の形態は術後ほぼ 1 年で一定化する。

稿を終えるにあたり，御指導御校閲を赐わりました千葉大学脳 神経外科牧野博安教授, 御指導睗加りました筑波大学腷神経外科 牧 豊教授，また御助言くださいました同中田義隆助教授，御 協力頂きました千葉大学脳神経外科堀江 武 助教授, 同 河野守 正講師に深く感謝申し上げます。

本諭文の要旨は，第39回 日本腷神経外科学会総会(1980年10月， 金沢)江扮いて発表した。

\section{文献}

I) Badell-Ribcra A, Shulman K, Paddock N: The relationship of non-progressive hydroccphalus to intellectual functioning in children with spina bifida cystica. Pediatrics 37: 787-793, 1966

2) Bøtlcher J, Jacobsen S, Gyldenstcd C, Harmsen \&, Gloerselt-Tarp B: Intellectual dcvelopment and brain size in 13 shunted hydrocephalic children. Neuropaediatrie 9: $369-377,1978$

3) Epstein F, Naidich TP, Chase NE, Kricheff II, Lin JP, Ransohoff $\mathbf{J}$ : Role of computerized axial tomography in diagnosis and treatment of common neurosurgical problems of infancy and childhood. Childs Brain 2: 111131,1976

4) Epstein F, Naidich TP, Kricheff II, Chase NE, Lin JP, Ransohoff $\mathrm{J}$ : Role of computerized axial tomography in diagnosis, treatment of follow-up of hydrocephalus. Childs Brain 3: 91-100, 1977

5) Foltz EL, Shurtleff DB: Five-year comparative study of hydrocephalus in children with and without operation (113 cases). I Neurosurg 20: 1064-1078, 1963

6) Gooding CA, Carter A, Hoare RD: New ventriculographic aspects of the Arnold-Chiari malformation. Radiology 89: 626-632, 1967

7) Halliwell MD, Carr JG, Pearson AM: The intellectual and educational functioning of children with neural tube defects. Z Kinderchir $31: 375-381,1980$ 
8) 入會梊郎, 谷 諭, 加藤康雄, 関野宏明, 中村紀夫 : 小児水頭症の長期予後。小児の脑神 $6: 85-92 ， 1981$

9）伊東 洋，小野寺良久，高梨邦彦，由島贀一，三輪哲郎 : 先天性水頭症病態の子後考察(第 2 報)一特に術後経過, 生存例の機能的予後一，媨神外科 $3: 313-322 ， 1975$

10) Klein DM, Berger PE: A comparison of computed tomography and air ventriculography in diagnosis of progressive hydrocephalus of infancy. Childs Brain 5: 272-280, 1979

11) Laurence KM, Coates $S$ : The natural history of hydrocephalus. Detailed analysis of 182 unoperated cases. Arch Dis Child 37 : 517-521, 1962

12) Laurence KM: Neurological and intellectual scquelac of hydrocephalus. Arch Neurol 20: 73-81, 1969

13) Lonton AP: The relationship between intellectual skills and the computerized axial tomograms of children with spina bifida and hydrocephalus. $Z$ Kinderchir 28 : 368-374, 1979

14) Lorber J, Zachary RB: Primary congenital hydrocephalus Longterm results of controlled therapeutic trial. Arch Dis Child 43: 516-527, 1968

15）森 惟明, 半田 肇 : 先天買常の臨床と CT. 東京, にゅーろん社, 1979

16) Naidich TP, Epstein F, Lin JP, Kricheff II, Hochwald GH: Evaluation of pediatric hydrocephalus by computed tomography, Radiology 119: 337-345, 1976

17) Naidich TP, Pudlowski RM, Naidich JB: Computed tomographic signs of the Chiari II malformation III: ventricle and cistcrn. Radiology 134:657-663, 1980

18) 中田義隆, 榎本貴夫, 牧豊 : シャント機能不全例 について一著明な檤室拡大を呈さない淀例の検討一. 第 8 回日本小巟神経外科学研究会, 長崎, 1980

19）中村三郎, 古賀信憲, 坪川孝志, 森安信雄 : 水頭症に お汀るShunt 術後の媨打よび脳室の变化. CT 研究 2： 45-51, 1980

20) Raimondi AJ, Soare P: Intellectual development in shunt hydrocephalic children. Am J Dis Child 127: 664-671, 1974

21) Rubin RC, Hochwald G, Tiell M, Liwnicz B, Epstein F : Reconstitution of the cerebral cortical mantle in shunt- corrected hydrocephalus. Dev Med Child Neurol [Suppl] 17: $151-156,1975$

22) Rubin RC, Hochwald GM, Tiell M, Epstein F, Ghatak N, Wisniewski M: Hydrocephalus: III Reconstitution of the cerebral cortical mantle following ventricular shunting. Surg Neural 5: 179-183, 1976

23) Shurtleff DB, Foltz EL, Loeser JD: Hydrocephalus a definition of its progression and relationship to intellectual function, diagnosis, and complications. Am $J$ Dis Child 125: 688-693, 1973

24）田中千凱，安藤 隆，佐藤好永，坂田一記：水頭症に対 する脳室心房連䅂術と脑室腹腔連絡術掞よびその遠隔成 績. 腷と神 $24: 265-273,1972$

25）谷 定泰, 河村悌夫, 草野孝文, 山内康雄, 松村 浩： 小北水頭症に対するシャント手術後の slit-like ventricle 13 症例の検討，小览の腷神 $6: 33-40,1981$

26) Tew B, Laurence KM: The effects of hydroccphalus on intelligence, visual perception and school attainment. Dev Med Child Neurol [Suppl] 17: 129-134, 1975

27) Tromp CN, van den Burg W, Jansen A, de Vries SJJM: Nature and severity of hydrocephalus and its relation to later intellectual function. $Z$ Kinderchir $28: 354-360,1979$

28) Weller RO, Shulman K: Infantile hydrocephalus: Clinical, histological, and ultrastructual study of brain damage. $J$ Neurosurg 36: 255-265, 1972

29) Yashon D, Jane JA, Sugan O: The course of severe untreated infantile hydrocephalus. $J$ Neurosurg 23: 509516,1965

30) Young HF, Nulsen FE, Weiss MH, Thomas P: The relationship of intelligence and cerebral mantle in treated infantile hydrocephalus ( $1 Q$ potential in hydrocephalic children). Pediatrics 52: 38-44, 1973

31) Zimmerman RD, Breckbill D, Dennis MW, Davis DO: Cranial CT findings in patients with meningomyelocele. AJR 132: 623-629, 1979

〔別刷請求先：干286 成田市飯田町 90-1, 成田赤十字病院脑 神経外科，加藤 誠] 